\title{
O EXÍlIO NA POESIA: LEITURAS DE GUTA (AS TR̂̂ES MARIAS) E EDNA (RIACHO DOCE)
}

\author{
Ricardo Gaiotto de Moraes \\ Universidade Federal de Santa Catarina (UFSC) \\ rgaiotto@gmail.com \\ Viviane da Silva Vieira \\ Pontifícia Universidade Católica de Campinas (PUC-Campinas) \\ vivianevieira.contato@gmail.com
}

\begin{abstract}
RESUMO
Publicados em 1939, As três Marias, de Rachel de Queiroz, e Riacho Doce, de José Lins do Rego, têm em comum protagonistas mulheres, cujas trajetórias são marcadas por experiências escolares distintas, mas, ao mesmo tempo, por uma convivência intensa com literatura escrita (romances, poemas) e oral (narrativas e canções populares). Pontuando as diferenças de registro, pois em As três Marias as memórias de Guta são registradas em primeira pessoa e em Riacho Doce a trajetória de Edna é narrada em terceira pessoa, este artigo procura estudar como as formações literárias das personagens marcam suas expectativas em relação ao futuro e provocam reflexões acerca dos limites impostos às mulheres na sociedade na qual as narrativas estão inscritas.
\end{abstract}

Palavras-chave: Cenas de leitura. Educação literária. Romance brasileiro.

\section{EL EXILIO EN POESÍA: LECTURAS DE GUTA (AS TRÊS MARIAS) Y EDNA (RIACHO DOCE)}

\section{RESUMEN}

Editados en 1939, As Três Marias, de Rachel de Queiroz, y Riacho Doce, de José Lins do Rego, tienen en común protagonistas femeninas, cuyas trayectorias están marcadas por diferentes experiencias escolares, pero al mismo tiempo, por una intensa convivencia con la literatura escrita (novelas, poemas) y oral (narraciones populares y canciones). Acentuando las diferencias en el registro, ya que en As Três Marias los recuerdos de Guta se registran en primera persona y en Riacho Doce la trayectoria de Edna se narra en tercera persona, este artículo busca estudiar cómo las formaciones literarias de los personajes marcan sus expectativas en relación al futuro y provocan reflexiones sobre los límites impuestos a las mujeres en la sociedad en la que se inscriben las narrativas.

Palabras claves: Escenas de lectura. Educación literária. Novela brasileña.

\section{THE EXILE IN POETRY: READINGS BY GUTA (AS TRÊS MARIAS) AND EDNA (RIACHO DOCE)}

\footnotetext{
ABSTRACT

Published in 1939, As Três Marias, by Rachel de Queiroz, and Riacho Doce, by José Lins do Rego, have in common women protagonists, whose trajectories are marked by different school 
experiences, but, at the same time, by an intense coexistence with written literature (novels, poems) and oral literature (narratives and popular songs). Punctuating the differences of record, because in "As Três Marias" Guta's memories are recorded in first person and in "Riacho Doce" Edna's trajectory is narrated in third person, this article seeks to study how the literary formations of the characters mark their expectations regarding the future and provoke reflections about the limits imposed on women in the society in which the narratives are inscribed.

Keywords: Reading Scenes. Literary education. Brazilian novel.

\section{L'EXIL DANS LA POESIE: LECTURES DE GUTA (AS TRES MARIAS) ET EDNA (RIACHO DOCE)}

\section{RÉSUMÉ}

Publié en 1939, As Três Marias, de Rachel de Queiroz, et Riacho Doce, de José Lins do Rego, ont en commun des femmes protagonistes, dont les trajectoires sont marquées par des expériences scolaires différentes, mais, en même temps, par une coexistence intense avec la littérature écrits (romans, poèmes) et oraux (récits et chansons populaires). Ponctuant les différences d'enregistrement, car dans As Três Marias les souvenirs de Guta sont enregistrés à la première personne et dans Riacho Doce la trajectoire d'Edna est racontée à la troisième personne, cet article cherche à étudier comment les formations littéraires des personnages marquent leur les attentes vis-à-vis de l'avenir et suscitent des réflexions sur les limites imposées aux femmes dans la société dans laquelle s'inscrivent les récits.

Mots-clés: Scènes de lecture. Éducation littéraire. Roman brésilien.

\section{INTRODUÇÃO}

Publicados em 1939, As três Marias, de Rachel de Queiroz, e Riacho Doce ${ }^{1}$, de José Lins do Rego, têm em comum mulheres protagonistas, cujas trajetórias são marcadas pela passagem por estabelecimentos escolares. Tal marca aparece impressa nas memórias de Maria Augusta, a narradora de As três Marias, e na constituição de Edna, personagem principal de Riacho Doce. Embora as experiências sejam distintas, dadas as especificidades de cada enredo e a forma de narrar, é no ambiente criado pelas narrativas que as personagens se deparam com a prática da leitura literária e da escuta das "dramáticas histórias de vida e impulsos libertários" (HOLLANDA, 2019, p. 13) contadas pelas colegas de internato, no caso de Guta, e das

\footnotetext{
${ }^{1}$ Os romances As três Marias e Riacho Doce foram estudados na dissertação de mestrado: VIEIRA, Viviane da Silva. Representações do estrangeiro no romance brasileiro de 1930: literatura, cultura e política. 2020. 257f. Dissertação (PPG em Linguagens, Mídia e Arte) - Pontifícia Universidade Católica de Campinas, Campinas-SP. Disponível em: http://tede.bibliotecadigital.puc-campinas.edu.br:8080/jspui/handle/tede/1355. A pesquisa foi realizada com bolsa da Fundação de Amparo à Pesquisa do Estado de São Paulo, FAPESP, processo n. 2018/11834-3.
} 
libertárias histórias da professora Ester em oposição às narrativas de caráter mais conformista que a mãe contava na infância, no caso de Edna.

Partindo da leitura das cenas que figuram o contato das protagonistas com narrativas, tanto escritas como orais, que descrevem a convivência com o ambiente escolar, este artigo procura estudar como essas vivências, organizadas pelos enredos de As três Marias e Riacho Doce, marcam a trajetória das personagens e dialogam com os limites impostos pela sociedade na qual as narrativas estão inscritas. Para isso, em um primeiro momento, o artigo apresenta os romances, perscrutando nos enredos como o contato das personagens com narrativas literárias, orais e artísticas de maneira geral marca a trajetória de encontros e desencontros com as possibilidades de destinos das personagens; em um segundo momento, elabora considerações comparativas entre os dois livros.

\section{AS TRÊE MARIAS}

Muito diferente da primeira edição de $O$ Quinze, de mil exemplares e paga às expensas da autora, As três Marias, quarto romance de Rachel de Queiroz, foi recebido pela crítica como a obra de uma romancista já conceituada. A impressão de que o livro apresentava traços autobiográficos foi apontada por Mário de Andrade em texto publicado em sua coluna do Diário de Notícias, em 17 de setembro de 1939. Para o crítico, a feição autobiográfica era perceptível, mas não roubava toda a atenção do romance, cujos conflitos femininos, a delicadeza e o trabalho psicológico da personagem-narradora sobressaíam e davam grande valor à obra (ANDRADE, 1955, p. 116). Mas a própria Rachel de Queiroz confirmaria que o livro era o mais autobiográfico de sua produção, apesar de conter muita ficção. Maria José foi inspirada na amiga Alba Frota, cuja vida familiar e pessoal foi representada no livro (a romancista diz respeito à profissão da amiga e às traições do pai de Alba), com exceção dos detalhes, esses trabalhados ficcionalmente. Já Maria da Glória, era Odorina Castelo Branco Sampaio, órfã, mãe de 13 filhos, cuja vida, para a amiga, era tão rica e importante que quase a inspirou completamente. Além das duas, também reconheceu que as outras colegas do colégio existiram e tiveram suas histórias recontadas na obra, apenas os nomes foram modificados para preservar suas identidades. Na vida de Guta, porém, inseriu uma história e uma trajetória ficcional, apesar de reconhecê-la como a personagem que a representava: "Eu não ia me confessar assim. Quando Guta vem para o Rio, eu soltei a imaginação. O Isaac nunca existiu, o filho, o aborto, eu só tinha ido ao Cariri uma vez na minha vida" (MENDES, 1998, p. 32,). Ainda que uma questão 
relevante para a recepção do romance, para os objetivos deste artigo, consideraremos o livro como as memórias da narradora Maria Augusta.

Em tom memorialístico, As três Marias, de Rachel de Queiroz, percorre diversos momentos da vida de Guta, como a entrada no colégio; a formatura e o retorno à casa da família, onde a protagonista não conseguiu se adaptar à rotina e à família e, na primeira oportunidade, convenceu o pai a permitir que se empregasse como datilógrafa em Fortaleza; os anos morando com Maria José e sua família; a viagem de férias ao Rio de Janeiro; e, por fim, a decisão derradeira de residir definitivamente com a família nas páginas finais. Os caminhos e os dramas pessoais das duas amigas, Maria da Glória e Maria José, são acompanhados dos tempos de colégio à vida adulta.

Estabelecida em Fortaleza, aos 18 anos, Guta temia não conhecer o mundo. Após a infelicidade com o suicídio de Aluísio - o amigo cuja culpa da morte relegaram a ela - e o desastroso envolvimento com o pintor Raul, partiu para férias no Rio de Janeiro. Pela primeira vez na vida, Guta considerava-se completamente livre, sensação que, de início, era desesperadora - a moça se sentia sozinha e inútil em meio àqueles desconhecidos. Em oito dias, porém, já estava habituada à cidade e às pessoas. Da amizade com Isaac, um médico rumaico que estudava para revalidar o diploma e poder se estabelecer definitivamente no Brasil, surgiu um namoro frustrado pelo retorno de Guta ao Ceará. Sua partida, contudo, estava marcada pelo medo de uma gravidez fora do casamento - tabu social que a condenaria por toda a vida. Após um aborto espontâneo, Guta teve notícias do retorno de Isaac à Europa, seguida de sua mudança para o sertão. A Guta que retornava à casa paterna, contudo, não era a mesma de anos antes. A protagonista retornava resignada com uma culpa que, supostamente, acreditava precisar carregar, assim como uma sensação de frustração de, apesar das tentativas de romper com suas barreiras morais, só ter intensificado sua vida social como inadaptada.

\section{GUTA: ENTRE LITERATURA, OUTRAS ARTES E DECEPÇÕES.}

Nas últimas páginas de As três Marias, já no trem de volta para a casa do pai, Guta conta-nos levar na sua bolsa quatro cartas de Isaac, no entanto afirma: "De que servem palavras escritas? Valem menos do que qualquer das palavras ditas, do que todas as queridas palavras que o vento do mar carregou" (QUEIROZ, 2019, p. 213).

Ainda que esteja relacionada às cartas "mortas, agora, inexpressivas e vazias" (QUEIROZ, 2019, p. 213) testemunhas do relacionamento frustrado, a consideração ressentida de que a palavra escrita nada vale diante da palavra dita parece também aludir ao cavalo de 
batalha de Guta contra o lirismo exagerado responsável por transformar o romance em narrativa amorosa ilusionista e os versos em cantilena de paixões frívolas. A recusa à ilusão romanesca se configura em As três Marias como resistência ao bovarismo que a educação da mulher na sociedade patriarcal representada parece forjar. Pelo menos, aos olhos de Guta, que identifica tal descolamento da realidade nas ilusões amorosas sonhadas por ela e pelas colegas nos três momentos narrados nas memórias: no internato, quando sonhavam com o pretendente árabe de Glória; já fora do internato, quando trabalhava como datilógrafa, tanto no jogo de sedução na qual se vê envolvida pelo pintor Raul, quanto no amor não correspondido, sequer externalizado, por Aluísio, estudante sonhador; no refúgio no Rio de Janeiro, após ser apontada injustamente por amigos e familiares de Aluísio como responsável pelo suicídio do rapaz Aluísio, quando conhece quem transformará sua vida, o médico judeu Isaac.

Narrando os tempos do internato, é a lembrança do contato com a história de vida das outras meninas, sobretudo Maria da Glória e Maria José, que disparará na escrita a lembrança da relação com a literatura. Maria da Glória perdera a mãe, o pai nunca superara o luto e escrevia à amada versos que, mesmo após a morte prematura dele, permaneceram colados no "cofre de madeira cheirosa" (QUEIROZ, 2019, p. 29) lembrança sempre carregada pela órfã como objeto de memória dos pais, eram:

Versos à morta, versos de saudade e mágoa revoltada. E outra espécie de versos também, esses alegres ou comovidos, acompanhando musicalmente a infância da filha, o primeiro sorriso, o primeiro dente, o primeiro passo. Pequenos cromos que, aos oito anos, Glória devia recitar nas festas da escola, com a mãozinha mostrando o céu, "onde a mamãezinha a esperava". (QUEIROZ, 2019, p. 29-30).

Os versos, alegres ou tristes, lembravam insistentemente a menina da falta da mãe, marcavam a impossibilidade do fim do luto e a permanência do pai em um mundo fantasmagórico, como se ele e a filha estivessem sempre na presença da falecida. Recordandose de sua tenra infância, Guta flagra em seu pai uma íntima convivência com a poesia enquanto a mãe era viva. Dos versos então declamados pelo pai, a narradora lembra que "comoviam tanto, embora [...] não os entendesse direito", por isso muitas vezes se calava, deixava só o pai "dizendo as palavras, porque a emoção me fechava a garganta e aquela hélice da história, enorme e vagarosa [...] sentia me bater dentro do peito" (QUEIROZ, 2019, p. 65). A mãe, “espécie de anjo leviano e sorridente" (QUEIROZ, 2019, p. 59) lhe morre cedo, o pai casa-se outra vez e a relação com a nova esposa, ao contrário da vivida com a mãe de Guta, é pautada pela ordem. O pai teria se tornado um homem sério, sem mais propensão ao lirismo: 
Agora tudo isso é história perdida, esquecida. Papai é severo, é outro, trabalha muito, está gordo, gordo como a família toda. Onde estão os seus livros? Ele agora só lê jornal. Onde estão as poesias que você me ensinava de noite, no alpendre, eu deitada com você na rede de corda, nós dois olhando a grande lua vermelha que ia subindo, nós dois repetindo os versos. (QUEIROZ, 2019, p. $65)$.

Para o pai de Glória, a poesia se confundia à necessidade de manter a memória da esposa viva e era a única linguagem possível para a vida fantasmagórica ao lado da morta. Para o pai de Guta, o sonho de uma vida de aventura se esvai com a morte da esposa, à medida que o tempo de luto termina, abandona a poesia e a leitura dos romances. A linguagem inefável da literatura é substituída pelo pragmatismo da linguagem jornalística. Para a narradora, o tempo desfeito da poesia foi também o da experiência na qual mais se aproximou como testemunha de uma relação tão leve na qual o pai "que soube querer e desfrutar o sutil encanto da vida ao lado de mamãe" nunca lhe reparou "a inconsequência, a desordem, a criancice" (QUEIROZ, 2019, p. 64).

"Tenho tudo na memória" (QUEIROZ, 2019, p. 59) nos conta Maria Augusta ao se lembrar de uma caixa, onde a madrasta guardara os objetos pertencentes a sua mãe. Dentre as roupas e os acessórios usados pela mãe no casamento, estavam os romances românticos $A$ Moreninha, de Joaquim Manuel de Macedo, As Meninas Exemplares, da condessa de Ségur, e um caderno de modinhas copiadas pela mãe, cujo hábito de leitura eram também pautados na idealização e nas leituras reservadas à educação das moças. Nas memórias de infância da narradora, a literatura ocupa um espaço complexo o qual conjuga tanto a recordação de uma relação familiar feliz, embora as descrições da mãe sugiram que ela fosse ainda muito jovem, quanto a fugacidade e a improbabilidade dessa experiência no mundo metrificado de regras sociais rígidas, representado pela madrasta - a narradora mais de uma vez se espanta com a leveza que a relação entre o pai e a mãe tinha a seus olhos de menina.

As lembranças da presença da literatura na infância são atravessadas pelas impressões da narradora sobre as leituras partilhadas com as colegas no internato, pautadas em livros cujo enredo era o amor idealizado. Lia, "como adolescente, como a quase mulher" na qual ia se "transformando depressa", "róseos romancinhos franceses, em que homens cheios de espírito e de tédio, cansados das sereias e dos paradoxos, se apaixonam pelas ingênuas de 16 anos" (QUEIROZ, 2019, p. 43). Ao registrar suas memórias, Guta não deixa de encaminhar críticas contra a formação recebida para se transformar em mulher, constituída pela leitura de narrativas nas quais a idealização amorosa apresentava-se como possibilidade de um futuro feliz. Na visão 
da narradora, esses enredos não só alienavam, como também não correspondiam à realidade, conforme vai sendo demonstrado pelo sofrimento das colegas depois de deixarem o internato. Jandira, criada pelas tias, longe da mãe prostituta, parecia quando solteira não se dobrar facilmente à opressão sofrida pelas mulheres, no entanto se casa com um marinheiro - de acordo com Guta, uma "profissão romântica", cuja imagem era de "uma espécie de poeta inconsciente e o mar", "o fundo ideal para todos os idílios" (QUEIROZ, 2019, p. 86) - que irresponsavelmente acaba levando-a ao sofrimento e à bancarrota. Maria José, energicamente reprimida pelas freiras por se apaixonar por outra garota na época do internato, acaba quando adulta sem outra alternativa a não ser morar com a mãe, ajudar a cuidar de seus irmãos e frequentar fervorosamente a igreja, isso devido a sua história familiar - o pai havia abandonado a mãe. Ambas histórias questionam a idealização corrente nos romances de moças referidos de que a completude da vida para a mulher se daria com um casamento.

Não só os romances comporiam as cenas de leitura da época do internato, Guta confessa que estava envolta, sufocada, raptada pela poesia. No entanto, não se tratava da "grande e divina poesia", eram "sonetinhos sentimentais, nas coisas leves e triviais do amor", versos fáceis "dum poeta de boudoir" os quais lhe enchiam "os olhos de água” (QUEIROZ, 2019, p. 43-44). No tempo da enunciação, Guta reconhece esses dois diferentes tipos de poesia, a sentimental e a divina. Os versos do primeiro tipo são os mais presentes na adolescência, fizeram parte de sua formação, agora ela os reconhece como ingênuos e, o desenvolvimento do enredo nos leva a concluir que foram prejudiciais; os do segundo tipo parecem ter tocado a narradora posteriormente. Menciona ainda um terceiro tipo de poesia, a satírica, produzida por Guta, Glória e Maria José no jornal Santa Gaiola, “'hebdomadário satírico e independente’, marcado ao canto com as estrelas das Três-Marias, impresso a mão, em tinta roxa e ilustrado a lápis de cor", escrito quase todo em verso, pois, de acordo com a narradora, "a literatura destrutiva prefere os moldes concisos da poesia” (QUEIROZ, 2019, p. 32). Diante desse posicionamento, nossa tarefa seria auscultar se essa grande poesia mostra seus rastros no decorrer do romance.

Ao sair do internato, Guta passou curto tempo na casa da madrasta e do pai e, depois de participar de um concurso público, mudou-se para Fortaleza, onde exerceria a função de datilógrafa em uma repartição pública, passou a morar na casa de Maria José. Lá se apaixonou por um pintor decadente casado, Raul. A cena do primeiro encontro se passa no teatro, durante os intervalos entre os atos da ópera Carmen, de Bizet, ainda enleada pelo dueto com as promessas de amor de Carmen e D. José, Guta troca insistentemente olhares com um "homem de cabeleira grisalha". Embora nem o final da ópera nem a descrição inicial do pretendido "era feio, débil, pequeno" - pareçam indicar bom agouro para o encontro, Guta afirma que, para 
ela, Raul "tinha um ar de romance, talvez um ar de grandeza interior". Romance como aqueles lidos em sua adolescência, cujas tramas levavam a imaginar relacionamentos idealizados que poderiam tornar possível o exílio em um mundo no qual mulheres como ela pudessem ser felizes. A narradora nos confessa ter sentido inconscientemente, "ainda sob a influência das doces melodias e do sex-appeal do tenor", "naquele homem um ar falso e teatral" (QUEIROZ, 2019, p. 104).

Após ser apresentada ao pintor por um amigo em comum dias mais tarde, Raul convida Guta para ser modelo em seu ateliê. Faria um retrato de Guta, intitulado "A datilógrafa". Ao narrar a decepção do momento em que viu pela primeira vez seu retrato pintado em linhas angulosas - "feia, esquematizada em traços rígidos" -, talvez em pastiche meio impressionista meio cubista, Maria Augusta mais uma vez descarrega o seu rancor em relação à idealização proposta não apenas pela literatura ou pela ópera, mas agora também por outra arte, a pintura:

- Pois eu me acho tão diferente aí [no quadro]... Nem me reconheço.

Raul riu:

- E o conteúdo interior?

Eu, frivolamente, olhava o traço, a semelhança bonitinha. Mas a expressão, o sentido íntimo é que o interessava: “-E essa, creio que a apanhei. Consegui mesmo registrar a melhor das suas expressões, esse seu meio sorriso de lábios descaídos".

Calei-me, lisonjeada, ao vê-lo se interessar tanto pelas minúcias da minha expressão. Mas no fundo não acreditei bem, fiquei pensando que ele talvez não fosse afinal o grande pintor que a gente daqui dizia, pobre gente que nunca viu nada e não pode ter opinião sobre artistas.

Ou então, a arte era realmente mais uma decepção. (QUEIROZ, 2019, p. 114115).

O desabafo de Guta, "a arte era realmente uma decepção”, ecoará em todo o livro. Tomando o advérbio "realmente" não apenas a partir do sentido de intensidade, mas de modo, a arte na realidade (na vida real), por sua impotência de representar a impossibilidade de felicidade e inteireza de escolha para as mulheres, e para a narradora em específico, se constitui como decepção. Isso devido à configuração patriarcal tanto da sociedade na qual está inserida, quanto do imaginário pertencente à literatura e às artes que costumava consumir. Guta narradora, desconfiada da sinceridade das intenções do pintor - "mas no fundo não acreditei bem" -, desacredita a arte de uma função de resistência, embora, para o leitor, o movimento parece ambíguo, pois é na encenação do processo de escrita autobiográfica que se depara com o testemunho feminino diante da opressão.

Passada a relação frustrada com Raul, quando se muda para o Rio de Janeiro, Guta conhece Isaac, por quem se apaixona. Estrangeiro, rumaico e médico, ele estava estudando para 
fazer uma prova para revalidar seu diploma no Brasil. Narrando os momentos felizes passados com Isaac, Guta narra uma cena em que estão em um café. Ele entrega-lhe um livro e pede a ela que o leia enquanto ele estudava, pois não conseguiria se concentrar pensando nos passeios dela sozinha pela cidade, justifica afirmando: "Se me lembrar de que está passeando, deixo tudo e vou atrás de você...” (QUEIROZ, 2019, p. 185). Embora haja certa cordialidade na frase de Isaac, também é possível observar a imobilidade de Guta, ela permanece sentada no café, isolada, sem possibilidade de expressar-se, talvez como muitas personagens femininas de romance cujas vontades foram silenciadas. "Basta uma pessoa se fechar com os seus pensamentos para colocar entre si e nós toda uma fronteira, com soldados, limites, e um mar desconhecido separando" (QUEIROZ, 2019, p. 186) reflete a narradora asseverando ainda mais o sentimento de solidão. É então que a desconfiança em relação à literatura ganha outra conotação: "Depressa comecei a me sentir sozinha, abandonada no meio de tanto livro, no meio daqueles estranhos silenciosos, agarrado cada qual com a sua leitura, tendo na minha mão um volume cujo nome mal entrevira, desconhecido como tudo o mais ali” (QUEIROZ, 2019, p. 186).

O isolamento daqueles estranhos em relação a ela e dela em relação a eles se dá no refúgio do gesto passivo de leitura. No fundo, um livro de memórias é um gesto solitário de exílio nas próprias recordações, mas também uma tentativa de diálogo com o outro - o leitor. O caso com Isaac terminou quando Guta voltou a Fortaleza, sua licença do trabalho expirara. Ela se descobre grávida, e quase ao mesmo tempo sofre um aborto. Na volta para a casa de Maria José, levou novos livros os quais alinhou na prateleira - "volumes de capa amarela que me falavam de Isaac e de minutos sonhados e perdidos" (QUEIROZ, 2019, p. 194). Os livros se transformam em objetos de recordação que enraízam a memória ${ }^{2}$, mas permanecem impotentes. Sabemos notícias de Isaac depois da separação pela carta transcrita no livro:

(Lembra-se dos versos de Villon: “Jehanne, la bonne Lorraine?" Um dia os lemos juntos, na Biblioteca.) Por falar em versos, mando-lhe hoje um pequeno volume de André Spire, pobre id como eu, pequeno e solitário, cheio de secretas tristezas. E ao me despedir, digo-lhe como ele diz às crianças, num poema que eu the peço leia logo: "Il y a trop de baisers pas donnés entre nous...”. (QUEIROZ, 2019, p. 200).

A menção aos poetas e à lembrança da leitura em conjunto constroem no tecido da memória as imagens românticas tantas vezes aludidas, mas, ao mesmo tempo, tais recordações

\footnotetext{
${ }^{2}$ A relação entre memória e objeto a partir do que Pierre Nora define: "A memória se enraíza no concreto, no espaço, no gesto, na imagem, no objeto" (NORA, 1993, p. 9).
} 
são ecos de que a poesia era "mais uma decepção". Não apenas restaram muitos beijos não dados, mas também muitos poemas não realizados, aludindo também à íntima relação entre a poesia e os casais apaixonados descritos no livro - os pais de Maria da Glória e da narradora. Na descrição desses (des)encontros, o deslocamento provocado pela diferença temporal entre enunciação e enunciado permite à narradora olhar criticamente suas experiências, elaborando as cenas de leitura como contrapontos entre o entusiasmo da paixão ilusória e a dura realidade do papel feminino subalterno modelo dos relacionamentos de então.

A potência de certo tipo de literatura em corroborar a hegemonia patriarcal seria confrontada, embora em latência, pelos versos satíricos do jornal que as estudantes elaboraram no internato, pelo vislumbre de uma verdadeira poesia e pelo próprio gesto da escrita das memórias inscrito na narrativa de As três Marias. Como afirma Cássia Santos, "sob a capa aparente de um romance de formação e sob o disfarce de um relato memorialístico, o romance de Rachel de Queiroz comporta um outro livro dentro de si: as memórias da protagonista" (SANTOS, 2020, p. 8), e é nesse livro que está a potência do exílio nas palavras, não mais isoladas à medida que produz diálogo com os leitores.

\section{RIACHO DOCE}

Publicado pela editora José Olympio, Riacho Doce não faz parte dos romances de José Lins do Rego que compunham o "Ciclo da cana-de-açúcar” e retratavam o Nordeste açucareiro. As obras independentes ao Ciclo, dentre elas, Riacho Doce, não alcançaram o mesmo destaque e prestígio com o passar dos anos; críticos pouco familiarizados aos escritos de José Lins ou determinados a diminuir a qualidade literária de seus textos, chegaram a considerar esse seu pior romance. No que concerne ao título e ao povoado fictício recriado, parece se referir ao bairro alagoano homônimo, notabilizado na década de 1930 pelas pesquisas petrolíferas ali desenvolvidas. Como relata Bernardo Buarque de Hollanda (2012, p. 150), entre 1926 e 1935 Lins do Rego morou em Maceió (AL) e, dado seu costume de passear, durante as manhãs, com a família, pelas praias da redondeza (costume emprestado a algumas de suas personagens, dentre elas, à Edna, protagonista de Riacho Doce), provavelmente conheceu o local nesse período e se inteirou das discussões acerca da prospecção. Quando perguntado sobre como surgiu a inspiração para o romance, o autor relatou a Aurélio Buarque de Holanda ter ocorrido durante uma conversa com uma amiga que o aconselhou a escrever sobre os fatos contados a ela. Na entrevista, o romancista não entrou em detalhes sobre a identidade da amiga ou do quê "tinha conhecimento", preferindo relegar a ideia a uma causalidade natural que afirmava 
sempre acontecer quando escrevia um romance: "Como sucedeu com todos os meus romances, a ideia de escrever Riacho Doce me apareceu de repente. Conversando com uma grande amiga sobre um caso do meu conhecimento" (HOLANDA, 1991, p. 358).

\section{EDNA: ENTRE HISTÓRIAS, MÚSICAS E DECEPÇÕES}

Riacho Doce tem como eixo os acontecimentos que envolvem a vida de uma jovem sueca chamada Eduarda, mas de apelido Edna. O romance tem o enredo dividido em três partes: "Ester", "Riacho Doce" e "Nô". A narrativa inicia-se com Edna relembrando as circunstâncias em que ela e o marido, Carlos, vieram para o Brasil. Vivendo há dois anos em Riacho Doce, ela rememora a infância na Suécia, os anos vividos como pupila da professora Ester, os primeiros tempos de casamento, assim como a mudança e o estabelecimento no povoado alagoano. "Ester" é a parte dedicada às recordações da infância e aos anos passados junto à família marcados, principalmente, pela passagem da professora Ester pela região. Desde criança, Edna desejava partir em busca de aventuras como as das histórias contadas pela mãe, como as que supunha viver o pai da amiga Norma, um homem do mar, livre para conhecer o mundo e viajar a países distantes e tropicais. A proximidade com Ester marca a fase em que deixa a infância e lida com as mudanças da adolescência. Após o conhecimento adquirido pelos livros lidos e pelas aulas da professora, Edna sentia-se transformada, de "outra gente", em um completo alheamento à família.

A segunda parte centra-se na fase adulta de Edna, na qual ela se muda com o marido para o vilarejo de Riacho Doce, no litoral alagoano. Após o casamento, Edna deixou do povoado natal e mudou-se para Estocolmo, onde assistiu ao teatro e à ópera, aproximando-se, assim, do mundo apresentado a ela, anos antes, por Ester. Vivendo em Estocolmo, o casal recebeu dos médicos a sugestão de que uma viagem além-mar poderia restituir o equilíbrio de Edna e a fazer superar a intensa melancolia da qual sofria desde a infância. A mera constatação da oportunidade de viver em um país tropical já muda Edna temporariamente. Tratava-se da realização do sonho antigo, acalentado desde a infância. A oportunidade surge quando Carlos, seu marido, torna-se o engenheiro de petróleo contratado para a exploração de petróleo em Riacho Doce. Deslumbrada pela paisagem, pelo clima tropical e pelos dias entregues ao mar e ao sol, Edna sente-se como vivendo em um de seus sonhos mais íntimos. Na terceira parte, o retorno de Nô a Riacho Doce e a paixão que os envolve enche de felicidade os dias de Edna. 
Embalada em poesia está também Edna, protagonista de Riacho Doce. Na infância, seu terror era a avó, uma mulher forte, intimidadora, cuja presença fazia com que os outros falassem baixo. Para a garota, influenciada pelas histórias de fantasia, a avó era um daqueles monstros cruéis e poderosos das histórias que a mãe contava: conta-nos que a velha Elba "fora muitas vezes, na sua meninice, a imagem dos dragões de contos de fada. Quantas vezes com seu irmão Guilherme não imaginara destruir o monstro, criando armadilhas, inventando precipícios onde a velha se despedaçasse, abismos que tragassem aquele terror!" (REGO, 1956, p. 18).

E por que via a avó como um ser que inspirava medo? Porque em oposição a ela estava a mãe. Frágil, apática e submissa, Matilde tinha pouca beleza ou qualidades aos olhos da filha. Apesar das duras críticas dirigidas à mãe, a menina Edna sentia rancor da servidão à qual a avó submetia a nora, por isso, junto com o irmão, procurava se vingar contrariando suas vontades. Pobre mãe presa sob as garras e as vontades do dragão Elba, fantasiava. De belo, de seu, Matilde tinha a voz doce e delicada, tão bonita que parecia um passarinho quando cantava - "Era tudo que ela tinha de seu, de particular: a sua voz, que soava como um gemido de instrumento em surdina (REGO, 1956, p. 19). Como seu oposto, a voz de Elba era forte, como trovões, voz de quem nasceu para o mando, para aterrorizar as pessoas.

Vivendo no pequeno burgo no interior da Suécia, o acesso às outras partes do mundo era restrito às histórias contadas pela mãe. Era com deleite que a menina, aos dez anos, ouvia falar de um mundo repleto de heróis, reis e cavaleiros corajosos e conquistadores, personagens das histórias populares que se transfiguravam, na imaginação da criança, nas tensões familiares - a avó cruel, a mãe, criatura indiferente, mas com voz linda e com o dom de contar histórias. Assim, até a chegada de Ester e o estreitamento da relação entre ambas, Edna conhecia o mundo a partir das histórias de tradição oral, passada da mãe para os filhos.

Suas histórias favoritas sempre envolviam um conquistador aventureiro, um personagem com liberdade e coragem para conhecer e experimentar o que tinha de mais bonito e atrativo no mundo. Para Edna, afeita à diferença, a beleza residia no que estava distante da sua realidade. As terras mais interessantes eram as tropicais, sempre quentes e com sol abrasivo, o mar e o verde abundantes compunham o sonho longínquo. Os personagens com os quais mais se identificava eram os conquistadores, os que nasceram livres para conhecer esse mundo idealizado em seus sonhos, os reinos distantes das histórias que ouvia.

Depois que Edna passou a frequentar as aulas com a professora Ester, essa concepção de mundo começou a mudar. Antes de sair de férias pela primeira vez, Ester foi à casa de Edna conversar com a família da menina e prometeu, quando retornasse, dedicar uma atenção adicional à educação dela, cujo interesse e dedicação apontava um grande futuro nos estudos. 
Ao despedir-se da já tão querida amiga, Edna chorou muito e só se acalmou quando a mãe, comovida por suas lágrimas, a levou ao quarto para acalmá-la com suas histórias. Naquela noite, ouviu uma de suas favoritas: a do rei que havia se disfarçado de mendigo para conhecer as necessidades do povo, mas também para testar sua bondade. No momento da separação, o mundo conhecido pelo rei não tinha nada bonito, apenas tristeza e misérias; sem Ester, Edna via-se sem nenhuma esperança de ser feliz, por isso, não queria ser como o rei, sentia pena dele assim como de sua mãe.

A mãe levou-a para o quarto, quis também dar o seu pedaço de conforto, e naquela noite contou-lhe uma de suas histórias favoritas, a história do rei que se fizera de mendigo para conhecer o mundo, as dores, os sofrimentos dos homens, as desventuras dos que não eram reis. Bem que a voz de sua mãe era como algodão que ela botasse por cima de suas feridas. $\mathrm{O}$ rei mendigo andava de porta em porta, esmolando. Para cada um ele tinha um pedido, mostrava a sua miséria, e viu as misérias dos outros, viu infelicidade no mundo. Viu casas de ricos negando-lhe pão e viu casas de pobres abrindo-lhes as portas. A mãe contava para a filha infeliz, e Edna foi chegando para o sono. Lá fora era o mundo que o rei saiu a vigiar. Ester se fora, a avó Elba ficava, a pobre mãe sempre fraca, o pai sem forças. Tudo seria ruim, tudo sem esperanças para ela. Ouviu o canto do rei implorando piedade. Pobre do rei que saíra pelo mundo! Como era pesado o destino dos que, como ele, pretendiam ver o mundo! Pobre mãe! (REGO, 1956, p. 22).

Nas férias, durante a ausência de Ester, ela se envolveu em uma aventura digna dos reis das suas histórias: roubou a Espanhola. A boneca pertencia à Norma; para Edna, a garota era uma carcereira malvada que prendia a Espanhola em uma caixa com a desculpa de que assim a conservaria em melhor estado. Influenciada pelas histórias das quais gostava, fantasiava o planejamento do roubo como a salvação da rainha Mary Stuart (1542-1587), da Escócia, figura histórica mantida presa por dezenove anos. Espanhola era parecida tanto com Ester, com os cabelos negros e a pele morena, como com a rainha, prisioneira de uma tirana. Em sua fantasia de libertação do brinquedo, ela comparava seu ato com os do rei Carlos, que diferentemente do rei angustiado das narrativas da mãe, assumiria o papel do homem forte e corajoso que libertaria a mocinha em perigo: "De sua cama Edna se media e avaliava a sua ação. Não havia dúvida de que realizara um feito glorioso. O rei Carlos teria sentido esta mesma alegria que ela estava sentindo, após a primeira batalha vencida" (REGO, [1939] 1956, p. 31). O rei sueco Carlos XII (Carolus Rex) (1682-1718) foi um grande estrategista militar e assumiu o poder aos quinze anos, por isso, Edna se refere a ele diversas vezes como "o rei menino". A personagem se identifica com um "herói" (jovem como ela), como se, ao salvar a Espanhola, ocupasse um 
papel masculino e ativo e não mais a passividade daquela donzela à espera da salvação presa em sua torre.

Com o passar dos anos, a Edna que roubou a Espanhola e comparou sua aventura às dos reis, se transformou, cresceu. Aos catorze anos, "Edna sentia que se despegava de casa, que não tinha mais ligação alguma com os seus. Era já de outra gente, de outro sangue. Tinha pena da mãe, terror da velha Elba, desprezo pelo seu pai. Com Sigrid e Guilherme não podia contar" (REGO, 1956, p. 37). Com a ajuda de Ester, avançou nas aulas de piano, aprendendo a tocar tão bem quanto a mestra, conheceu outras histórias, as dos romances, dos livros de poesia emprestados pela amiga e afastou-se mais da família - "Era quase uma moça: tinha 14 anos feitos, se adiantara em piano, lera muito. Muitos romances lhe abalaram a sensibilidade, e os poetas de Ester eram os seus" (REGO, 1956, p. 37). As histórias da mãe já não a atraíam, a própria mãe se torna uma figura apagada para ela.

Mesmo quando chega à idade adulta, Edna continua mantendo viva a lembrança de Ester e do que aprendeu com ela: havia, lá fora, um mundo amplo, cheio de oportunidades que iam além da vida conhecida por sua família; havia a oportunidade de ser o oposto da mãe, ser livre, feliz. Após cinco anos de silêncio e separação, recebeu uma carta de Ester, primeiro passo para sua libertação. Com a carta em mãos, emocionada, Edna lia repetidamente e a cada vez ouvia com mais nitidez a voz de Ester, falando diretamente aos seus ouvidos: "Era a voz de Ester, a doce voz de veludo que lhe recitava os poemas, que soletrava as palavras, medindo, com aquele timbre de cristal" (REGO, 1956, p. 68). Mesmo as palavras mais singelas escritas por Ester, como seu nome, são transformadas em poesia, ritmadas pela pulsação do sangue retumbando nas veias, nos ouvidos de Edna. As palavras da amiga despertaram-na para a vida, tirando-a da apatia a qual se encontrava - "Era a doce voz. Os poemas saíam assim com aquela sequência, aquele ritmo sereno. E ela lhe falava de tudo" (REGO, 1956, p. 69).

O principal efeito das palavras de Ester é impulsionar Edna para o rompimento definitivo com a família. Nos anos anteriores, sentindo-se culpada pelo sofrimento causado à professora após a tentativa de suicídio, a jovem manteve-se junto à família e assumiu a maior parte dos trabalhos braçais com a plantação e o trato dos animais. Entretanto, sabendo que Ester estava bem, era feliz e vivia no mundo paradisíaco dos sonhos de Edna, a moça sente-se livre, perdoada e pronta para reivindicar àquela felicidade descrita na carta. Se Ester era feliz na Argentina, apesar de todo o sofrimento por ser judia, pobre e sozinha na Europa, Edna também poderia ser, só precisava partir - "A carta de Ester viera-lhe como um grito de alguém que se salvara de um poço. Um brado de vida, uma advertência" (REGO, 1956, p. 72). Os anos de sofrimento ocasionados pelo amor não correspondido e não compreendido por Ester pareciam 
próximos ao fim. A primeira parte do romance, encerra-se, justamente, com a esperança do início de uma nova vida longe dali.

Dias e dias se passaram após a chegada da carta. Ester desaparecera como por encanto, mas uma coisa maior, mais intensa de proporções, se criara para Edna. A terra da boneca de Norma, o claro país de sol, das flores, da música doce, aparecia: surgira para ela como um último recurso de seus sonhos. Levou noites inteiras com o mundo de Ester, sonhando com Ester. (REGO, 1956, p. 73).

Desse modo, quando se casa com Carlos e vai para Estocolmo, é o mundo apresentado por Ester, anos antes, que ela conhece. Na capital, reata com a cultura erudita após os anos de isolamento, vai à ópera, ao teatro, ao cinema, compra revistas e livros sobre música, por fim, aproxima-se de Saul. Também Carlos ganha sua atenção por apreciar a música; naqueles tempos em que a lembrança de Ester está novamente fresca, é o entendimento de mundo aprendido com ela que Edna considera mais essencial, por isso o casamento. Edna achava Carlos bom, mas ingênuo, os olhos azuis e o semblante de menino indicavam que não via o mundo como ela; Carlos não sofria e sentia com a intensidade da esposa ("Era simpático, embora aquela cara de menino, aqueles olhos azuis, limpos demais, olhos sem certa profundeza, de quem não via a vida de perto" (REGO, 1956, p. 78)).

Ao lado das recordações de Ester, mesmo se esforçando, Edna dificilmente viria a amálo com a intensidade que amara a imagem construída da antiga professora. Ester era justamente uma imagem, uma criatura amada e idolatrada, mas cuja figura pouco correspondia à pessoa real; nos momentos de intimidade em que relata sua vida à aluna mais dedicada, Ester desabafa para quem se sentia mais próxima, aos poucos, revelando informações sobre sua verdadeira personalidade. A relação com Roberto, mantida oculta de Edna durante o desabafo, por romper com a imagem idealizada criada pela adolescente, é usada como gatilho para a frustração do amor não correspondido, ocasionando na tentativa de suicídio. As rejeições aos outros homens que propuseram casamento era resultado das suas expectativas desse amor ideal, arrebatador, que a viria dominar por completo assim como a música; Edna sabia que não poderia, como a irmã, Sigrid, ou Norma, se casar com um homem da região, uma figura que lhe lembrasse o pai. Acima do desejo de fugir àquela estrutura patriarcal e com poucas opções para as mulheres de sua classe social, Edna esperava um sentimento tão arrebatador quanto o sentido por Ester, “esperava por um furacão, uma força desencadeada que viesse movê-la de seu canto. Até ali Ester lhe impedira desafiar os elementos. Havia uma culpa a redimir. Agora não, o seu maior anseio era descobrir num lugar qualquer alguém que pudesse agitá-la, dobrá-la aos seus 
desejos" (REGO, 1956, p. 73). Esse amor arrebatador a dominará mais duas vezes: com a mudança para Riacho Doce, quando se encontra em contato direto com a natureza; e quando conhece Nô. Assim, nos meses seguintes ao casamento,

Edna tinha a impressão de que havia saído da prisão, dos trabalhos forçados, para uma liberdade absoluta. Seis meses levou meio tonta com a liberdade. Não havia concerto, teatro, cinema a que não fossem. A música de Ester devia ser a sua companheira preferida. Deu para ler sobre música e para comprar revistas que falassem nessas coisas. Era o meio que tinha de se ligar com o mundo novo em que vivia. Carlos tinha amigos que só falavam nisso. Havia um judeu, seu colega de trabalho, engenheiro-chefe de seu escritório, que era como se fosse um profissional de orquestra. Só conversava sobre música. Chamava-se Saul e era casado com uma mulher egoísta, que não ia com os entusiasmos do marido. Indignava-se até com aquela insistência de só falar em tal assunto. (REGO, 1956, p. 79).

Como Ester, Saul também era apaixonado por música e é considerado por Edna como um mestre, um companheiro com o qual compartilha do mesmo entusiasmo; é visto como um substituto que provisoriamente ocupava o espaço deixado pela outra. Por ser o laço que a unia à Ester desde a infância, a música tem um importante papel na vida de Edna. Sua identificação com Saul é reforçada pela impressão de que Carlos, apesar de apreciar os concertos, "ouvia música como a maioria"; aos olhos de Edna, para ele, uma valsa de Chopin ou uma sonata de Beethoven entravam e saíam sem causar transformações, ao passo que Saul, Ester e ela tinham a música como uma religião, como um Deus cuja força transformadora chegava às profundezas de suas almas e os tocava por completo: "O Deus de Ester e de Saul penetrava de casa adentro, ia atrás das almas, nas suas maiores profundezas, nos seus mais recônditos esconderijos. Carlos não era assim" (REGO, 1956, p. 80).

A apreciação de Edna pela música, antes da mudança para o Brasil, era um vínculo profundo criado com Ester e, posteriormente, com Saul; em Riacho Doce, a princípio, o coco é considerado uma melodia triste, apesar de ela não conhecer o suficiente da língua para entender a letra, "Edna ouvia bem que era triste o que ele cantava" (REGO, 1956, p. 99). Com o tempo o entendimento foi chegando, a impressão que causava em todos (de estar ali há mais tempo) também retumbava em seu íntimo. Riacho Doce é seu segundo amor, paraíso idealizado no qual ela depositava todas as fantasias de infância: havia um lugar verde, com sol abrasivo e mar quente, onde não caberiam tristezas, apenas felicidade e liberdade.

As impressões dela sobre a música brasileira em Riacho Doce, o coco, são transmitidas à irmã, em carta, no oitavo capítulo da segunda parte; o capítulo, é por ela entendido como uma confissão tão íntima e sincera que se poderia considerar como uma sessão de autoconhecimento, 
"Fazendo esta carta, parece que me satisfiz" (REGO, 1956, p. 148). Nas noites de lua, escreveu referindo-se à música, quando os nativos cantavam, ouvia e achava o canto triste, muito diferente da música da sua terra natal; eles não acompanhavam com o acordeão ao qual era habituada, o coco era cantado mesmo sem instrumento e era uma música feita para dança. Mas quando Edna os ouvia, era tomada do sentimento e da emoção sentida com a música de Ester: "Quando estou deitada e escuto o coco, dá-me uma tristeza terrível. [...] Sinto-me com a angústia que me deixava a música de Ester, como se o piano estivesse outra vez me chamando para ele" (REGO, 1956, p. 143-144). A sensibilidade à música se intensifica quando Edna, em contato com o coco, chega a questionar-se do porquê da música ser tão triste quando estavam rodeados de tantas belezas naturais.

Esse comentário revela mais sobre Edna do que sobre o coco: na Suécia, acreditava ser triste porque vivia em um país de inverno rigoroso; no Brasil, foi feliz naqueles primeiros meses, mas em breve a felicidade cessaria. A menção à natureza é sintomática da tristeza dela, uma vez que o capítulo seguinte à carta anuncia o início da temporada de chuvas e a chegada de uma vitrola e discos de concertos à casa. Assim, Edna afasta-se não apenas do mar, do sol e do verde intenso, mas também da cultura popular a qual vinha se aproximando; impossibilitada de sair, reata o laço com a música clássica: "Foi uma festa no primeiro dia. Ouviu música, encheu-se de música, pensou em Saul, em Ester, no mundo que deixara para os outros. Ouviu Chopin outra vez com o corpo inteiro, esperando por ele como por um amante" (REGO, 1956, p. 153).

A reaproximação com a música popular é definitiva com a chegada de Nô a Riacho Doce. Até então, ela metaforizara na música e no clima tropical o amante desejado, aquele furacão que chegaria com uma força desencadeada e que viria transformar seus dias. Esse furacão é Nô. Quando o vê, chega a desacreditar e pensar se ele não passava de um sonho, pois aquele homem parecia recém-saído de um conto: "E imediatamente, como num conto do Oriente, aparecia a seus olhos um homem, uma criatura de carne e osso, que era como todo o modelo de seus sonhos. Era sonho, fora miragem. Não podia ser verdade" (REGO, 1956, p. 164). Toda a romantização e a espera inquieta e silenciosa por esse homem, o amante de seus sonhos, completa a caracterização de Nô, era marinheiro e cantava como um passarinho. Homem livre do mar, Nô correspondia às fantasias de Edna quando menina: aos dez anos, ela também queria conquistar novos territórios e povos, desejava ser livre para se lançar ao mar e navegar. Quanto à voz do rapaz, era como a da mãe de Edna, um canto bonito a ponto de ser comparado aos dos passarinhos. Naquela primeira noite, Nô cantou e Edna, de sua casa, o ouviu. 
Meses depois, quando o relacionamento deles foi descoberto e se afastaram, ela o ouvia certa de que ele cantava para a atrair, para enviar um recado de amor:

Nisto ouviu-se um canto acompanhado de violão. Era Nô. A voz era dele. E ele cantava justamente aquilo que ela sempre lhe pedia, o seu canto de gajeiro. Era o seu homem se desmanchando para que ela ouvisse, para que ela soubesse que ele sofria por causa da branca. Era ele mandando de longe, de sua casa imunda, um recado de amor: "Edna, minha branca, eu estou te esperando: as águas do mar estão quentes, a areia da praia está morna, as ondas estão mansas, as espumas estão brancas; vem, Edna, vamos correr de praia afora. O Garça Torta corre frio de águas sujas para o mar, para o mar limpo. O Jacarecica se espalha na praia. Vem, querida, eu te levo de jangada para dentro do mar. Vamos correr sobre as ondas com a vela branca cheia de vento, nós dois pegados um no outro, amando, como dois fugidos do mundo...”. (REGO, 1956, p. 223).

Aos ouvidos de Edna, o canto de Nô é como um feitiço, cheio de promessas e pedidos apaixonados. É como o efeito do canto da sereia, chamando-a para o mar, arrastando-a para os braços do homem amado, esperado e idealizado. Sereia ou não, vítima do feitiço da voz de passarinho daquele praieiro ou não, é ao mar que Edna se entrega ao ter suas expectativas amorosas frustradas; assim como Ester e Riacho Doce, Nô também não seria dela. Sem mais forças para sonhar, nada em direção ao nascer do sol, ao consolo da morte.

\section{CONSIDERAÇÕES FINAIS}

Na infância, Guta e Edna atraíam-se pelas histórias de heróis corajosos que viajavam em busca de aventura e da conquista do mundo, o mesmo mundo que ambas tinham sede de conhecer. A influência dos livros na educação de Guta se dá à medida que ela cresce, os livros infantis dão lugar aos romances românticos, em maior de literatura francesa, leituras pautadas na idealização amorosa e direcionada à educação de moças. Por sua vez, Edna se desvencilha das histórias de tradição oral contadas pela mãe ao se aproximar da cultura erudita conhecida a partir do contato com a professora Ester. Apenas quando chega ao Brasil, já adulta, ocorre a reconciliação com a cultura popular, mas sempre marcada pelo retorno à música de Ester nos momentos de crise. Enquanto para Edna a educação formal teve o efeito de transformá-la, para Guta a escola foi apenas um presídio do qual sonhava sair. Chega a lembrar da irmã Germana e dos vários livros de exegese que havia lhe indicado procurando despertar nela a fé. O esforço em educá-la na fé católica foi, contudo, sem resultados; após várias leituras seguidas de debates com o pai, as irmãs e o padre reitor, o interesse da jovem logo passou. A jovem freira que 
também gostava de romances é vista com escândalo por ela, pois, ao contrário das amigas, jamais pode considerar as irmãs como amigas, como mestras queridas.

No prefácio à recente edição de As três Marias, Heloísa Buarque de Hollanda escreve uma "Carta aberta (talvez inútil e certamente atrasada a Rachel de Queiroz)" para reiterar o caráter feminista avant la lettre do livro (embora a autora de $O$ Quinze tenha sempre refutado tal caráter em suas obras), pois mesmo que a narração em primeira pessoa pudesse sugerir o caráter autobiográfico e a narrativa guinar para uma história de menina-moça, a escrita continuaria calculada e apareceria no enredo a complexidade da condição da mulher em meio à sociedade patriarcal. Seria possível encontrar na escrita da trajetória de Guta tanto "o leitmotiv de todas as personagens femininas, de Conceição a Maria Moura", ou seja, "a sina da perda/abandono do amado, a falta de descendência, a escolha de caminhos individuais e difíceis, a possível derrota e o final, sem exceção, num passo seguro em direção ao desconhecido" (HOLLANDA, 2019, p. 15), quanto um "dos diferenciais mais importantes da escrita feminista" na "forma fragmentada como as memórias são narradas" (HOLLANDA, 2019, p. 11).

No artigo que escreve para o rodapé "Vida Literária", Mário de Andrade destaca da estrutura de Riacho Doce a construção por meio de noções que em vez de "contadas e explicadas linearmente", como geralmente ocorreria no desenvolvimento de um enredo, apareceriam "muitas vezes e sempre a mesma, sem desenvolvimento, com uma constelação fixa de noções dela derivadas ou a ela associadas"”3 (ANDRADE, 1955, p. 146). O crítico explica que essa maneira de compor daria ao romance um aspecto de música, formando um "processo rítmico-musical comum aos aedos e rapsodistas, a um Homero, como a um Manuel do Riachão, e aparece com frequência no canto nordestino" (ANDRADE, 1955, p. 148). Ainda que não nos caiba, dado o escopo deste artigo, julgar a criação crítica do musicólogo Mário de Andrade, a imagem nos sugere um livro em que composição e enredo caminham paralelamente no que se refere ao encontro com a música popular.

Assim, se, no romance de José Lins do Rego, Edna se refugia no canto popular e, no livro de Rachel de Queiroz, Guta encontra guarida no próprio gesto da escrita das memórias, na poesia do canto e na poesia da escrita encontram as duas mulheres o exílio e, nos dois casos, esse lugar é o da incerteza: Edna se dilui nas águas, Guta desaparece no caminho de volta para casa. Ainda que a volta seja incerta, o exílio costuma também provocar no exilado a crítica em relação à sociedade que lhe expulsou.

\footnotetext{
${ }^{3}$ Para exemplificar o que define como noção, Mário de Andrade destaca três noções (1 - Volta de Nô; 2 - Nô e o canto; 3 - Nô e o amor") que se repetiriam como motivos ao longo de um mesmo capítulo do livro.
} 


\section{REFERÊNCIAS}

ANDRADE, Mário de. O empalhador de passarinho. 2. ed. São Paulo: Martins, 1955.

HOLANDA, Aurélio Buarque de. José Lins do Rego fala sobre seu novo romance. In:

COUTINHO, E. F.; CASTRO, A. B. de (Orgs.). José Lins do Rego: Coleção Fortuna crítica 7. Rio de Janeiro: Civilização Brasileira/João Pessoa: Edições Funesc, 1991. p. 357-360.

HOLLANDA, Bernardo Borges Buarque de. ABC de José Lins do Rego. Rio de Janeiro: José Olympio, 2012.

HOLLANDA, Heloisa Buarque de. Carta aberta (talvez inútil e certamente atrasada) a Rachel de Queiroz. In: QUEIROZ, Rachel de. As três Marias. 29. ed. Rio de janeiro: José Olympio, 2019.

MENDES, Marlene Gomes. As três Marias, de Rachel de Queiroz: edição crítica em uma perspectiva genética. Niterói: EDUFF, 1998.

NORA, Pierre. Entre história e memória: a problemática dos lugares. Revista Projeto História, n. 10, p. 7-28, 1993.

QUEIROZ, Rachel de. As três Marias. 29. ed. Rio de janeiro: José Olympio, 2019.

REGO, José Lins. do. Riacho Doce. 3. ed. Rio de Janeiro: José Olympio, 1956.

SANTOS, Cássia dos. O autobiográfico, o ficcional e o literário em um romance de Rachel de Queiroz. Todas as Letras, São Paulo, v. 22, n. 1, p. 1-15, jan./abr. 2020.

Recebido em: 14 de dezembro de 2020

Aceito em: 15 de dezembro de 2020 